\title{
Rannsóknir í læknisfræði, traust og fagmennska
}

Mikið hefur verið rætt og ritað um mál skurðlæknisins Paolo Macchiarinis og aðgerðir pær sem hann framkvæmdi á skjólstæðingum sínum, meðal annars ungum manni með ólæknandi krabbamein sem vísað var í góðri trú til meðferðar á Karólínska sjúkrahúsinu frá Landspítala í maí 2011. Málið, sem í daglegu tali hefur verið nefnt „plastbarkamálið“, er mikill álitshnekkir fyrir Karólínska sjúkrahúsið og Karólínsku stofnunina sem Macchiarini starfaði við frá árinu 2010, ekki síst eftir að í ljós kom að margir annmarkar voru á pessum lækningum og tilskilin leyfi skorti. ${ }^{1}$

Umræddur læknir hefur endurtekið verið staðinn að alvarlegum blekkingum sem rekja mætti í löngu máli. Saga Macchiarinis varpar ljósi á hvað getur gerst pegar stjörnudýrkun og ofurkapp um frægð og frama ber fagmennsku ofurliði. Vísindaáætlanir hans virðast hafa tekið mið af ofurtrú hans á eigin verðleikum og rétti til að leyfa tilganginum að helga meðalið. Málið hefur meðal annars leitt til afsagnar ritara sænsku Nóbelsnefndarinnar og aðstoðarrektors Karólínsku stofnunarinnar. •að teygir anga sína víða, par á meðal til Íslands vegna tilvísunar fyrsta sjúklingsins héðan. Páttur Landspítala og Háskóla Íslands hefur verið rannsakaður sérstaklega af priggja manna óháðri nefnd sem hefur nýlega skilað niðurstöðu í afar ítarlegri skýrslu. ${ }^{2}$

Læknablaðið hefur ekki verið vettvangur fyrir umræðu um petta mál fram að pessu. Pegar jafnflókin mál eru til rannsóknar á vegum margra nefnda, fyrst í Svípjóð og síðan hér á landi, er skynsamlegt að bíða með yfirlýsingar par til niðurstaða er fengin, ekki síst í fámennu samfélagi par sem umræða getur fljótt orðið ofskautuð og persónugerð.

Eftir kynningu á niðurstöðum rannsóknanefnda í Svípjóð og í kjölfarið íslensku nefndarinnar um plastbarkamálið er ljóst að ýmislegt hefði mátt betur fara í samskiptum íslensku og sænsku stofnananna tveggja. Par má nefna ábyrgð lækna við gagnkvæm samskipti, skráningu og upplýsingagjöf, og viðbrögð pegar erindum héðan var ekki svarað. Einnig dregur málið fram ábyrgð meðhöfunda að vísindagreinum, en nú liggur fyrir að 6 vísindagreinar sem Macchiarini er ábyrgðarhöfundur að, par á meðal vísindagrein sú sem lýsti fyrsta sjúkratilfellinu í Lancet, stóðust ekki pær kröfur sem gera verður til slíkra birtinga og bera allir höfundar par ábyrgð. Pá dregur skýrslan fram kerfisbundna misnotkun á trausti par sem eiginlegar klínískar prófanir voru ranglega kynntar sem lækningar sem stundaðar voru á samúðargrunni. ${ }^{1}$ Pá fjallar skýrslan um álitamál sem snerta kynningar á nýjungum í læknisfræði. Að auki telur íslenska nefndin að ígræðsla á gervibarka úr plastefni sem innihélt stofnfrumur, - tilraunameðferðin sem sjúklingurinn frá Landspítala gekkst undir í Svípjóð - hafi ekki aðeins verið leyfisskyld par heldur hafi einnig purft leyfi hér á landi. Sú niðurstaða vekur upp ýmsar áleitnar spurningar, ekki síst hvað pau tilvik snertir pegar íslenskir sjúklingar taka pátt í rannsóknum erlendis en eru síðan í áframhaldandi meðferð og eftirliti hér á landi. Í reynd hefur ekki verið litið svo á að eftirlit sjúklinga sem svo er ástatt um kalli á sérstakt umsóknaferli til siðanefnda hérlendis. Pessi ábending vekur pví fjölmargar spurningar og parf að skýra nánar. Megum við vænta pess að pegar sjúklingum er vísað til erlendra stofnana af innlendum læknum og taka í framhaldi af pví pátt í rannsókn erlendis en eru í áframhaldandi eftirliti hér sé læknunum par með skylt að gerast rannsakendur hér á landi með öllum peim skyldum sem pví fylgir?

Fleiri lærdóma má draga af plastbarkamálinu en tíundað er í skýrslunni. Pegar mistök eiga sér stað í heilbrigðispjónustu er gjarnan talað um að orsakir séu oftast kerfislægar fremur en að pær liggi í atferli tiltekinna starfsmanna. Pví er gagnlegt að skoða málið fyrst frá peim sjónarhóli.

Að sumu leyti varpar skýrslan ljósi á veikleika hins fámenna íslenska heilbrigðiskerfis, par sem sérpekkingu skortir á vissum sviðum og læknar purfa að reiða sig á tengsl við erlenda sérfræðinga og stofnanir og treysta ráðleggingum paðan. Í fullkomnu kerfi á hins vegar ekki að skipta máli hver er á vakt, skjólstæðingar heilbrigðiskerfisins geta gengið að góðri pjónustu vísri. Samræður peirra sem best pekkja til, teymisvinna og vönduð skráning á niðurstöðum er hluti lausnarinnar.

Í annan stað minnir petta mál á pað hversu mikilvægt er að vel sé staðið að undirbúningi klínískra rannsókna og stuðningi við pær. Pau sjónarmið heyrast gjarnan í krabbameinslækningum að óverjandi sé að aðeins 3\% sjúklinga taki pátt í klínískum meðferðarrannsóknum eins og raunin mun vera í dag. ${ }^{3}$ Án slíkra rannsókna er stöðnun óhjákvæmileg. Hvatar bæði sjúklinga og rannsakenda til pátttöku í slíkum rannsóknum purfa pó að vera heilbrigðir og eðlilegir, traust og fullvissa parf að ríkja milli beggja aðila um að allur undirbúningur standist skoðun. Mikilvægi pess er jafnvel enn meira pegar farið er út fyrir ramma gagnreyndrar læknisfræði. Allt orkar tvímælis pá gert er.

Pað ætti að vera öllum læknum kappsmál að efla fagmennsku og rannsóknir í læknisfræði hér á landi. Pað veldur pví nokkrum vonbrigðum að nýleg skýrsla frá NordForsk sýnir að eina háskólasjúkrahús Íslendinga, Landspítali, hefur dregist verulega aftur úr systurstofnunum sínum á Norðurlöndum hvað gæði vísindarannsókna snertir undanfarin 12 ár, próun sem hófst fljótlega eftir sameiningu spítalanna. ${ }^{4}$ Pekkt er að gæði klínískrar pjónustu og öflugar vísindarannsóknir haldast í hendur; eru tvær hliðar á sama peningi.

Ein versta útkoma fyrir skjólstæðinga heilbrigðiskerfisins úr plastbarkamálinu væri sú að í framtíðinni veigruðu læknar sér við að leita bestu leiða fyrir skjólstæðinga sína og hættu að taka pátt í rannsóknum og pekkingarsköpun. Раð er á ábyrgð okkar allra að koma í veg fyrir pað. Til pess að svo megi verða purfum við draga lærdóm af niðurstöðum skýrslunnar og styrkja pá umgjörð, samtal og aðstöðu sem læknum og sjúklingum er búin til vísindarannsókna hér á landi.

Heimildir

1. Fallet Macchiarini. Utredning av verksamheten med transplantationer av syntetiska luftstrupar vid Karolinska Universitetssjukhuset. Rapport 2016-08-31.

2. Plastbarkamálið. Skýrsla nefndar sem skipuð var af rektor Háskóla Íslands og forstjóra Landspítala hinn 27. október 2016. Reykjavík 2017.

3. Murthy VH, Krumholz HM, Gross CP. Participation in cancer clinical trials. Race-, sex-, and age-based disparities. JAMA 2004; 291: 2720-6.

4. NordForsk. Comparing research at Nordic higher education institutions using bibliometric indicators: Covering the years 1999-2014. Policy paper 4/2017, Osló.

The Editorial Board

Medical research, trust and professionalism

https://doi.org/10.17992//bl.2017.12.161 